\title{
Preliminary Study of Electricity Generation and Sulfate Removal Performance in a Novel Air-Cathode Microbial Fuel Cell (AC-MFC) Using Laccase-Producing Yeast as a Biocatalyst
}

\author{
Pimprapa Chaijak ${ }^{1 *}$, Chikashi Sato ${ }^{2}$, Noris Paucar ${ }^{2}$, \\ Monthon Lertworapreecha ${ }^{3}$, Chontisa Sukkasem ${ }^{4}$ \\ 'Department of Biotechnology, Faculty of Science, Thaksin University, Phatthalung, Thailand \\ ${ }^{2}$ Department of Civil and Environmental Engineering, College of Science and Engineering, \\ Idaho State University, Idaho, United States \\ ${ }^{3}$ Department of Microbiology, Faculty of Science, Thaksin University, Phatthalung,Thailand \\ ${ }^{4}$ Department of Food Science and Technology, Faculty of Agro and Bio Industry, \\ Thaksin University, Phatthalung, Thailandchaijak
}

Received: 23 May 2018

Accepted: 2 August 2018

\begin{abstract}
Fungi produce various types of extracellular enzymes, including the copper-containing oxidative enzyme laccase. This enzyme uses gaseous oxygen $\left(\mathrm{O}_{2}\right)$ as an electron acceptor to catalyze oxidation of phenolic compounds, and therefore it can act as a cathode biocatalyst in a microbial fuel cell (MFC). In this study, a new model of the air-cathode microbial fuel cell (AC-MFC) was constructed. For its design, the laccase-producing yeast Galactomyces reessii cultured in potato dextrose agar was grown in the cathode chamber, and an anaerobic microbial community was maintained in the anode chamber in order to carry out sulfate removal and, simultaneously, generate electricity. Results showed that the cathode with $G$. reessii outperformed the cathode with sterile gel (negative control), yielding the maximum open circuit voltage of $550.65 \pm 14.92 \mathrm{mV}$, the maximum power density of $0.35 \pm 0.01 \mathrm{~mW} / \mathrm{m}^{3}$, the maximum current density of $225.69 \pm 17.25 \mathrm{~mA} / \mathrm{m}^{3}$ and sulfate removal of $73.29 \pm 1.31 \%$. This study demonstrated the feasibility of using a yeast culture for continuous laccase production in the cathode chamber of the AC-MFC in order to improve their electricity generation and sulfate removal.
\end{abstract}

Keywords: laccase, microbial fuel cell, electrical power, wastewater treatment, rubber

*e-mail: pimprapa@gmail.com, 


\section{Introduction}

Microbial fuel cells (MFCs) can directly convert chemical energy contained in organic and inorganic materials into electrical energy by using bacteria capable of transferring electrons to an anodic electrode. This technology has been successfully demonstrated in the area of environmental biotechnology for treating wastewater and simultaneously generating electricity $[12,25]$. To obtain high electric power outputs, precious metals such as white gold and platinum $(\mathrm{Pt})$ have been used for a cathodic electrode in the MFC design, which tends to limit its practical applications.

White-rot fungi produce and secrete laccase, a multicopper oxidoreductase enzyme, in the environment to return nutrients from the plant material to the soil via lignin degradation. Laccase plays a role in transporting electrons from the phenolic compound and aromatic amine to electron acceptors such as oxygen $\left(\mathrm{O}_{2}\right)$. Accordingly, laccase has the potential to perform as a cathodic biocatalyst that transfers electrons to gaseous oxygen [9, 17]. Several researchers immobilized fungal enzymes on the electrode surface, and they found that fungal laccases from the white-rot fungi such as Ganodium lucidum, Trametes versicolor, and Pleurotus ostreatus enhanced the electric output $[2,5$, $8,13,23]$. The significant disadvantage of their MFCs, however, is that the enzyme extracted from the fungal sources needs to be purified. The purification of the enzyme is costly and involves additional handling and maintenance during the MFC operation, as the enzyme can be denatured to lose its activity under normal environmental conditions [13]. A previous study has addressed the problem by using whole fungal cells (rather than using the pure enzyme), and this approach outperformed the laccase-free controls and yielded high power outputs [8].

Various types of sulfate-contaminated wastewater are generated in the production processes of sugar, alcohol, pharmaceutical products, monosodium glutamate and natural rubber sheet. The engineered anaerobic treatment and natural anaerobic processes for sulfatecontaining wastewater generally result in the generation of hydrogen sulfide $\left(\mathrm{H}_{2} \mathrm{~S}\right)$ [3, 15], a toxic pollutant present in domestic wastewater, sludge discharged from anaerobic bioreactors and industrial off-gases. Because of its adverse characteristics, including being a health hazard and having objectionable odor and corrosive properties, the removal of $\mathrm{H}_{2} \mathrm{~S}$ from wastewater is necessary [10]. The conventional biological treatment of sulfate-contaminated sewage is a two-stage process. The first stage is the reduction of sulfate to sulfide by sulfate-reducing bacteria; then the reduction of sulfide to sulfur by sulfide-oxidizing bacteria [22]. This treatment system has several drawbacks, such as the large land requirement for the treatment units and a high cost of unit operation [21]. The study for sulfate-removal with simultaneous bioenergy recovery showed that the biological treatment with sulfate-reducing bacteria
(SRB) in a dual chamber MFC can be an attractive technique [14].

The major factors currently limiting practical applications of MFCs in wastewater treatment are their high construction, operation and maintenance costs. In the present work, the new type of AC-MFC was designed and constructed using a biocatalyst in place of the expensive platinum-based cathode. Because the laccase-producing yeast Galactomyces reessii continuously secretes laccase (biocatalyst) in the cathode chamber, the laccase-based AC-MFC can be applied cost-effectively to the wastewater treatment areas in the future. In this paper, the laccase-based AC-MFC was examined in terms of electricity generation and sulfate removal from synthetic rubber wastewater.

\section{Experimental}

\section{Microbes}

Anaerobic sludge was collected from a rubber wastewater treatment plant in Phatthalung Province, Thailand. A microbial community in mud was enriched and maintained in nutrient broth (NB) in a laboratory, and used in generating electricity and removing sulfate. The laccase-producing yeast G. reessii [4] was obtained from the Department of Biotechnology, Thaksin University, Thailand. G. reessii was maintained on potato dextrose agar (PDA).

\section{Gel-Cathode Preparation}

A plug of potato dextrose agar (PDA) containing 7-day-old G. reessii was cut to a $1.0 \times 1.0 \mathrm{~cm}$ piece that was inoculated into $100 \mathrm{~mL}$ of potato dextrose broth (PDB). The PDB was incubated at $30^{\circ} \mathrm{C}$ for 7 days with shaking at $150 \mathrm{rpm}$. An aliquot $(500 \mu \mathrm{L})$ of the incubated broth $(\mathrm{OD}=0.5$ at $600 \mathrm{~nm})$ was inoculated into $5.0 \mathrm{~mL}$ of PDA.

\section{Microbial Fuel Cell Design and Operation}

A schematic of a new model of the AC-MFC is presented in Fig. 1. The AC-MFC consisted of an anode chamber $(25.0 \mathrm{~mL})$ and cathode chamber (6.0). The anode chamber was open to the atmosphere. The anode $\left(2.0 \mathrm{~cm}^{2}\right)$ and cathode $\left(2.0 \mathrm{~cm}^{2}\right)$ were made of a plain carbon cloth (CC). The anode chamber was filled with $22.5 \mathrm{~mL}$ of anolyte containing $500 \mathrm{mg} / \mathrm{L}$ sulfate. One liter of the anolyte solution $(\mathrm{pH} 7)$ contained $5.24 \mathrm{~g}$ of $\mathrm{KH}_{2} \mathrm{PO}_{4}, 10.71 \mathrm{~g}$ of $\mathrm{K}_{2} \mathrm{HPO}_{4}$ and $0.74 \mathrm{~g}$ of $\mathrm{Na}_{2} \mathrm{SO}_{4}$. The sulfate concentration was measured by the turbidimetric method described in the standard methods [1]. Initially, $2.5 \mathrm{~mL}$ of a microbial community and nutrient broth $(1 \%$ $\mathrm{v} / \mathrm{v}$ ) were added as co-substrate to the anolyte, modified from Lai et al. [8] and Miran et al. [14].

In the treatment experiment, the cathode chamber was inserted into the anode chamber. The laccase- 


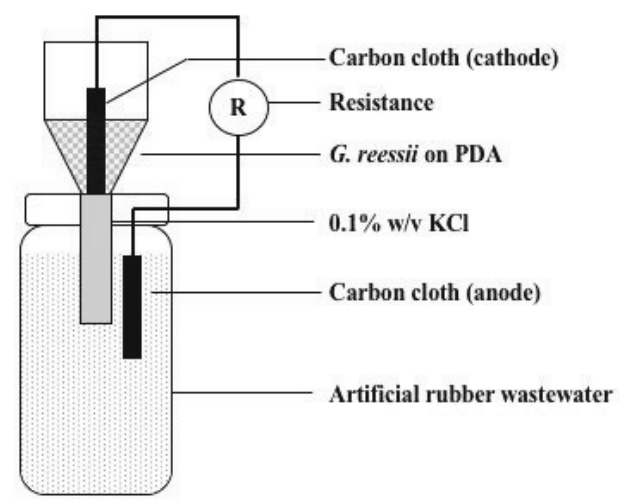

Fig. 1. Diagram of an air-cathode microbial fuel cell (AC-MFC).

based cathode was prepared by covering the plain $\mathrm{CC}$ $\left(2 \mathrm{~cm}^{2}\right)$ with 7-day old G. reessii culture. The Pt-coated $\left(0.3 \mathrm{mg} / \mathrm{cm}^{2}\right) \mathrm{CC}$ with $5.0 \mathrm{~mL}$ of sterile PDB served as the positive control and the plain $\mathrm{CC}$ with $5.0 \mathrm{~mL}$ of sterile PDB served as the negative control. The cathode and anode were connected with a stainless wire $(0.1 \mathrm{~cm}$ diameter, $5.0 \mathrm{~cm}$ length). The salt bridge gel was prepared according to previous studies $[19,20]$ with minor modifications, i.e., $1.0 \mathrm{~g} / \mathrm{L}$ of $\mathrm{KCl}$ and $10.0 \mathrm{~g} / \mathrm{L}$ of agarose were used. The gel was sterilized at $121^{\circ} \mathrm{C}$ for 15 mins. The bottom of the cathode chamber was filled with $500 \mu \mathrm{L}$ of $\mathrm{KCl}$ gel $(1 \% \mathrm{w} / \mathrm{v})$.

\section{Electrochemical Analysis}

The electrochemical properties were monitored by the method modified from the previous studies [8]. The laccase-based MFC (Lac-MFC), Pt-based MFC (Pt-MFC), and laccase-free MFC (Gel-MFC) were set up. The open circuit voltage (OCV) was determined within one day of operation. The internal resistance was calculated from the polarization curve produced at the external resistance of $150-2,150 \Omega \mathrm{s}$ according to $\mathrm{Wu}$ et al. [24].

The current and power were calculated as follows:

$$
\begin{gathered}
\mathrm{I}=\mathrm{V} / \mathrm{R} \\
\mathrm{P}=\mathrm{IV}
\end{gathered}
$$

...where I, V and R are the current (A), voltage (V) and resistance $(\Omega)$, respectively, and $\mathrm{P}$ is the power (W). The current density (CD) and power density (PD) were defined based on the anode volume, $\mathrm{V}_{\mathrm{A}}\left(\mathrm{m}^{3}\right)$ :

$$
\begin{aligned}
& \mathrm{CD}=\mathrm{I} / \mathrm{V}_{\mathrm{A}} \\
& \mathrm{PD}=\mathrm{P} / \mathrm{V}_{\mathrm{A}}
\end{aligned}
$$

...where $\mathrm{CD}$ and $\mathrm{PD}$ are the current density $\left(\mathrm{A} / \mathrm{m}^{3}\right.$ or $\left.\mathrm{mA} / \mathrm{m}^{3}\right)$ and power density $\left(\mathrm{W} / \mathrm{m}^{3}\right.$ or $\left.\mathrm{mW} / \mathrm{m}^{3}\right)$, respectively.

\section{Sulfate Removal}

The turbidimetric method was used for monitoring the sulfate removal from each round of operation. Briefly, $10.0 \mathrm{~mL}$ of treated anolyte (sample) was filtered through filter paper (Whatman No.1), then $4.0 \mathrm{~mL}$ of buffer solution $\left(30.0 \mathrm{~g} / \mathrm{L}\right.$ of $\mathrm{MgCl}_{2}, 5.0 \mathrm{~g} / \mathrm{L}$ of $\mathrm{CH}_{3} \mathrm{COONa}$, and $20.0 \mathrm{~mL} / \mathrm{L}$ of acetic acid) and $0.003 \mathrm{~g}$ of $\mathrm{BaCl}_{2}$ were added to the sample. After stirring, the absorbance of the mixtures was measured using a spectrophotometer at $420 \mathrm{~nm}$. The sulfate removal was calculated by:

$$
\text { Sulfate removal }(\%)=[(\mathrm{A}-\mathrm{B}) / \mathrm{A}] \times 100
$$

...where $\mathrm{A}$ and $\mathrm{B}$ are initial and final absorbance, respectively.

\section{Results and Discussion}

\section{Electricity Generation Characteristics of AC-MFC}

Fig. 2 shows the OCV produced by the Lac-, Ptand Gel-MFCs. The maximum OCV of the Lac-MFC is $550.65 \pm 14.92 \mathrm{mV}(\mathrm{n}=3)$ observed at 420 mins, while the maximum OCV of the Pt-MFC (positive control) and the Gel-MFC (negative control) are $664.65 \pm 30.00 \mathrm{mV}(\mathrm{n}=3)$ at $580 \mathrm{mins}$ and $193.68 \pm 7.46 \mathrm{mV}(\mathrm{n}=3)$ at 200 mins, respectively.

The closed circuit voltage (CCV) was determined in the range of the external resistances between 150 and $2150 \Omega$. The electrochemical properties of the Lac-MFC and Pt-MFC are shown in Table 1. Note that the output voltage of the Gel-MFC (negative control) could not be detected. The internal resistance of the Lac-MFC determined from the polarization curve (Fig. 3) at maximum power density is $330 \Omega$. The $\mathrm{CD}$ of the Lac-MFC increased with decreasing external resistance, yielding a maximum $\mathrm{CD}$ of $225.69 \pm 17.25 \mathrm{~mA} / \mathrm{m}^{3}$. The PD of the Lac-MFC increased from $0.08 \pm 0.01$ to $0.24 \pm 0.01 \mathrm{~mW} / \mathrm{m}^{3}$. On the other hand, the internal resistance of the Pt-MFC is $1002 \Omega$, maximum $\mathrm{CD}$ is $249.51 \pm 17.53 \mathrm{~mA} / \mathrm{m}^{3}$, and $\mathrm{PD}$ increased from $0.23 \pm 0.03$ to $0.35 \pm 0.01 \mathrm{~mW} / \mathrm{m}^{3}$.

In a study with the fungal laccase of Trametes versicolor entrapped on the surface of the air-cathode, Kacem et al. [6] obtained the maximum PD of $15.72 \mathrm{~mW} / \mathrm{m}^{3}$ after 24 days of its operation. Applications of this system, however, are limited by maintenance costs. Lai et al. [7] developed an AC-MFC using the edible white fungus Ganoderma lucidum that produces laccase. G. lucidum grown in PDA was placed on the carbon cloth cathode. They obtained the maximum $\mathrm{CD}$ and $\mathrm{PD}$ of $633.75 \mathrm{~mA} / \mathrm{m}^{3}$ and $224.98 \mathrm{~mW} / \mathrm{m}^{3}$, respectively. G. lucidum was also used by $\mathrm{Lin}$ et al. [11] as a biocathode in dual or two chambers MFC (tMFC). They observed the maximum OCV of $420 \mathrm{mV}$ 


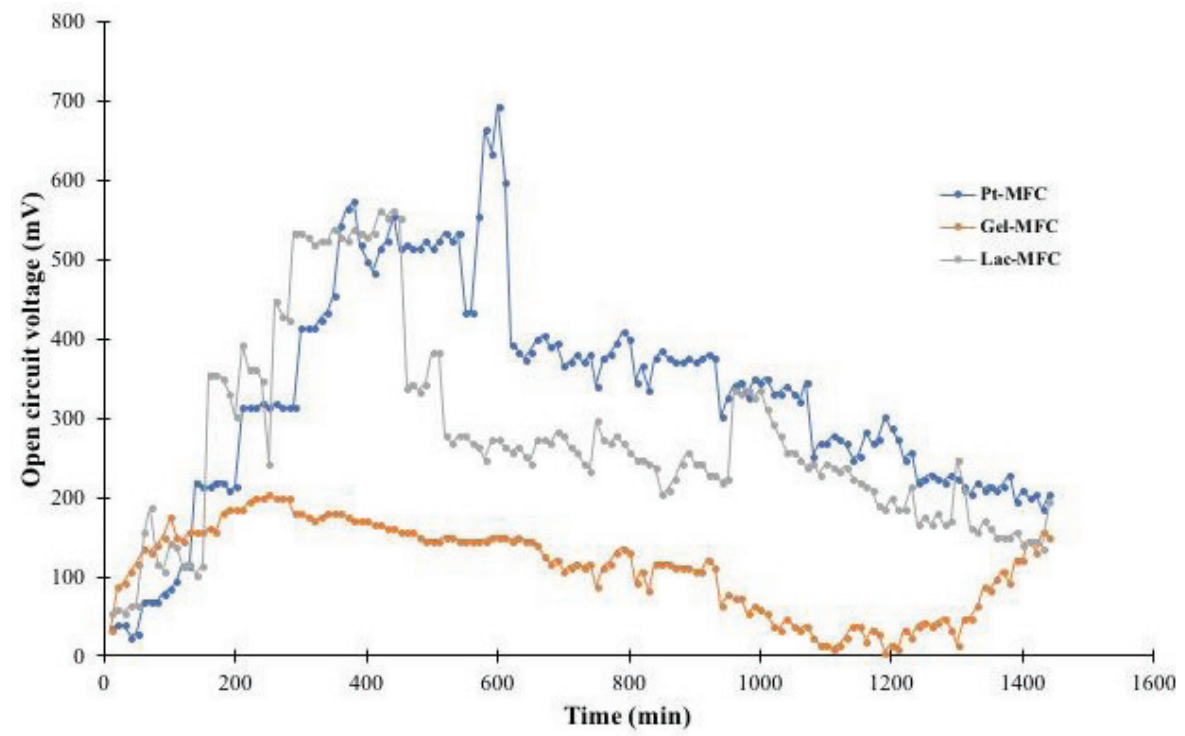

Fig. 2. OCV of three different cathodes in AC-MFC; artificial rubber wastewater was used as anolyte.

Table 1. Resistance, output voltage, current density (CD) and power density (PD) during the AC-MFC operation $(n=3)$.

\begin{tabular}{|c|c|c|c|c|c|c|}
\hline \multirow{2}{*}{$\begin{array}{c}\text { Resistance } \\
(\Omega)\end{array}$} & \multicolumn{3}{|c|}{ Pt-MFC } & \multicolumn{3}{c|}{ Lac-MFC } \\
\cline { 2 - 7 } & Voltage $(\mathrm{mV})$ & $\begin{array}{c}\mathrm{CD} \\
\left(\mathrm{mA} / \mathrm{m}^{3}\right)\end{array}$ & $\begin{array}{c}\text { PD } \\
\left(\mathrm{mW} / \mathrm{m}^{3}\right)\end{array}$ & Voltage $(\mathrm{mV})$ & $\begin{array}{c}\mathrm{CD} \\
\left(\mathrm{mA} / \mathrm{m}^{3}\right)\end{array}$ & $\begin{array}{c}\text { PD } \\
\left(\mathrm{mW} / \mathrm{m}^{3}\right)\end{array}$ \\
\hline 150 & $0.94 \pm 0.07$ & $249.51 \pm 17.53$ & $0.23 \pm 0.03$ & $0.85 \pm 0.06$ & $225.69 \pm 17.25$ & $0.19 \pm 0.03$ \\
\hline 270 & $1.30 \pm 0.01$ & $191.93 \pm 2.15$ & $0.25 \pm 0.01$ & $1.26 \pm 0.05$ & $186.05 \pm 6.95$ & $0.23 \pm 0.02$ \\
\hline 330 & $1.49 \pm 0.01$ & $180.82 \pm 1.33$ & $0.27 \pm 0.01$ & $1.41 \pm 0.01$ & $170.63 \pm 1.62$ & $0.24 \pm 0.01$ \\
\hline 1002 & $2.96 \pm 0.06$ & $118.08 \pm 2.20$ & $0.35 \pm 0.01$ & $1.89 \pm 0.10$ & $75.39 \pm 3.83$ & $0.14 \pm 0.01$ \\
\hline 2150 & $4.07 \pm 0.14$ & $75.71 \pm 2.68$ & $0.31 \pm 0.02$ & $2.13 \pm 0.15$ & $39.68 \pm 2.74$ & $0.08 \pm 0.01$ \\
\hline
\end{tabular}

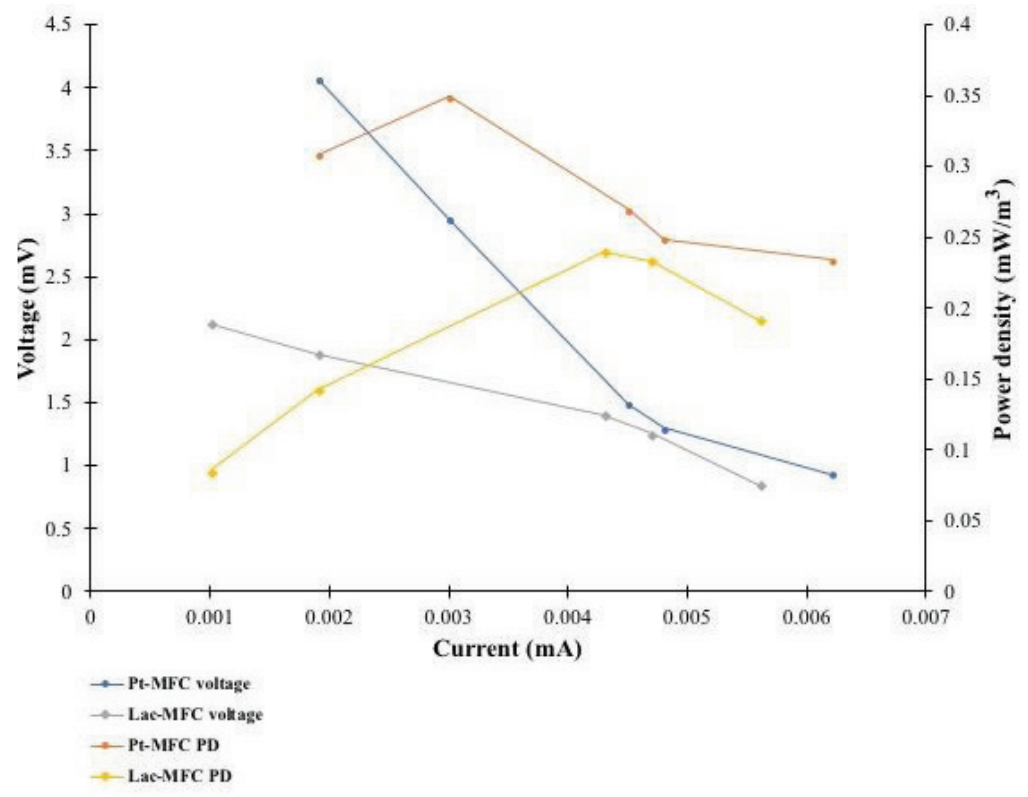

Fig. 3. Polarization curve and power density (PD) current curve of AC-MFC. 


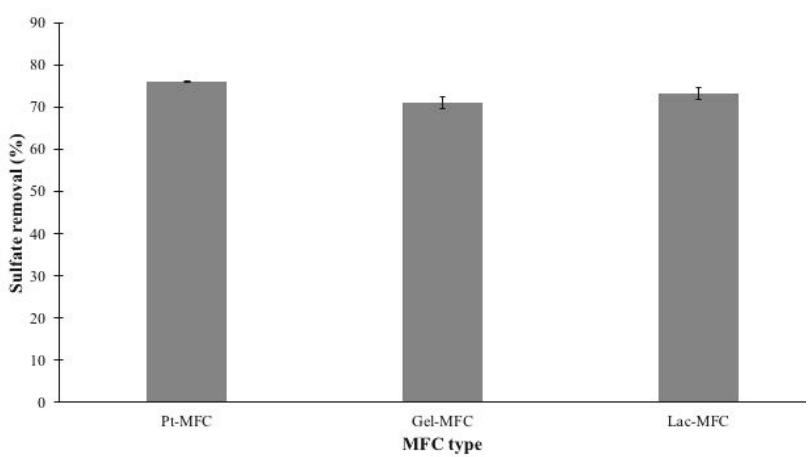

Fig. 4. Sulfate removal (\%) of AC-MFC when $500 \mathrm{mg} / \mathrm{L}$ sulfatecontaminated artificial rubber wastewater.

after 20 days of its run. Maximum $\mathrm{PD}$ and $\mathrm{CD}$ were $66.67 \mathrm{~mW} / \mathrm{m}^{3}$ and $333.33 \mathrm{~mA} / \mathrm{m}^{3}$, respectively. Note that the anode and cathode chambers were separated by a PVA hydrogel elastomer (polyvinyl alcohol) membrane.

\section{Sulfate Removal Efficiency}

In this study, synthetic rubber wastewater containing $500 \mathrm{mg} / \mathrm{L}$ sulfate was used. After 1 day of AC-MFC operation, sulfate removal by the LacMFC was $73.29 \pm 1.31 \%(n=3)$ while removal by the Pt-MFC (positive control) and Gel-MFC (negative control) were $76.17 \pm 0.23 \%(\mathrm{n}=3)$ and $71.13 \pm 1.43 \%$ $(n=3)$, respectively (Fig. 4). Miran et al. [14] treated synthetic wastewater using the tMFC by adding copper to stimulate the biological reactions. They obtained sulfate removal of $70 \%$ after running the tMFC for 2 days. Seo et al. [18] used the AC-MFC to remove sulfate from artificial wastewater containing $200 \mathrm{~g} / \mathrm{L}$ sulfate and obtained $17.6 \%$ sulfate removal after 10 days of operation.

\section{Conclusions}

The AC-MFC's performance can be enhanced by using fungal enzyme laccase for the air cathode as a biocatalyst. Nonetheless, the use of commercial laccase limits the MFC applications owing to its high costs. In this study, laccase-producing yeast $G$. reessii was used to catalyze the reduction of $\mathrm{O}_{2}$ on the surface of the aircathode. G. reessii grown on the $\mathrm{CC}$ cathode improved the MFC's usability, as this MFC model successfully removed sulfate from artificial rubber wastewater in a short period of time while generating electricity.

\section{Acknowledgements}

The authors would like to thank the Science Achievement Scholarship of Thailand for student scholarship support.

\section{Conflict of Interest}

The authors declare no conflict of interest.

\section{Referencess}

1. APHA. Standard Methods for the Examination of Water and Wastewater, 20 ${ }^{\text {th }}$ ed. In APHA, AWWA, WEF, Washington DC, USA. 1998.

2. BARTON S.C., PICKARD M., VAZQUEZ-DUHALT R., HELLER A. Electroreduction of $\mathrm{O}_{2}$ to water at $0.6 \mathrm{~V}$ (SHE) at $\mathrm{pH} 7$ on the wire Pleurotus ostreatus laccase cathode. Biosensors and Bioelectronics, 17 (12), 1071, 2002.

3. CELIS-GARCIA L.B., GONZALEZ-BLANCO G., MEREZ M. Removal of sulfur inorganic compounds by a biofilm of sulfate reducing and sulfide oxidizing bacteria in a down-flow fluidized bed reactor. Journal of Chemical Technology \& Biotechnology, 83 (3), 260, 2008.

4. CHAIJAK P., LERTWOPREECHA M., SUKKASEM C. Phenol removal from palm oil mill effluent using Galactomyces reessii termite-associated yeast. Polish Journal of Environmental Studies, 27 (1), 39, 2018.

5. FISHILEVICH S., AMIR L., FRIDMAN Y., AHARONI A., ALFONTA L. Surface display of redox enzymes in microbial fuel cells. Journal of American Chemical Society, 131 (34), 12052, 2009.

6. KACEM S.H., GALAI S., DE LOS RIOS A.P., FERNANDEZ F.J.H, SMAALI I. New efficient laccase immobilization strategy using ionic liquids for biocatalysis and microbial fuel cells applications. Journal of Chemical Technology and Biotechnogy, 93 (1), 174, 2018.

7. LAI C.Y., LIU S.H., WU G.P., LIN C.W. Enhanced biodecolorization of acid orange 7 and electricity generation in microbial fuel cells with superabsorbent-containing membrane and laccase-based bio-cathode. Journal of Cleaner Production, 166 (1), 381, 2017a.

8. LAI C.Y., WU C.H., MENG C.T., LIN C.W. Decolorization of azo dye and generation of electricity by microbial fuel cell with laccase-producing white-rot fungus on cathode. Applied Energy, 188 (15), 392, 2017b.

9. LEE H., JANG Y., CHOI Y.S., KIM M.J., LEE J., LEE H., HONG J.H., LEE Y.M., KIM G.H., KIM J.J. Biotechnological procedures to select white rot fungi for the degradation of PAHs. Journal of Microbiological Methods, 97 (1), 56, 2014.

10. LENS P.N.L., VISSER A., JANSSEN A.J.H., POL L.W.H., LETTINGA G. Biotechnological treatment of wastewater. Critical Reviews in Environmental Science and Technology, 28 (1), 41, 1998.

11. LIN C.W., WU C.H., LIN Y.Y., LIN S.H., CHANG S.H. Enhancing the performance of microbial fuel cell using a carbon-fiber-brush air cathode with low-cost mushroom Ganoderma laccase enzyme. Journal of the Taiwan Institute of Chemical Engineers, 85 (1), 115, 2018.

12. LOGAN B.E., RABAEY K. Conversion of wastes into bioelectricity and chemicals by using microbial fuel cell electrochemical technologies. Science, 337 (1), 686, 2012.

13. MANI P., KESHAVEZ T., CHANDRA T.S., KYAZZE G. Decolourisation of acid orange 7 in a microbial fuel cell with laccase-based biocathode: Influence of mitigating $\mathrm{pH}$ changes in the cathode chamber. Enzyme and Microbial Technology, 96 (1), 170, 2017. 
14. MIRAN W., JANG J., NAWAZ M., SHAHZAD A., JEONG S.E., JEON C.O., LEE D.S. Mixed sulfatereducing bacteria-enriched microbial fuel cells for the treatment of wastewater containing copper. Chemosphere, 189 (1), 134, 2017.

15. MOHAMMADI M., MAN H.C., HASSAN M.A., YEE P.L. Treatment of wastewater from rubber industry in Malaysia. African Journal of Biotechnology, 9 (38), 6233, 2010.

16. PINAR O., KARAOSMANOGLU K., SAYER N.A., KULA C., KAZAN D., Sayer A.A. Assessment of hazelnut husk as a lignocellulosic feed stock for the production of fermentable sugars and lignocellulolytic enzymes. 3 Biotech, 7 (6), 1, 2017.

17. POZDNYAKOVA N.N., RODAKIEWICZ-NOWAK J., TURKOVSKAYA O.V., HABER J. Oxidative degradation of polyaromatic hydrocarbons and their derivatives catalyzed of polyaromatic hydrocarbons and their derivatives catalyzed directly by the yellow laccase from Pleurotus ostreatus D1. Journal of Molecular Catalysis B: Enzyme, 41 (2), 8, 2006.

18. SEO Y., KANG H., CHANG S., LEE Y.Y., CHO K.S. Effects of nitrate and sulfate on the performance and bacterial community structure of membrane-less singlechamber air-cathode microbial fuel cells. Journal of Environmental Science and Health Part A-Toxic/ Hazardous Substances \& Environmental Engineering, 53 (1), 13, 2018.

19. SHIBATA M., KATO M., IWAMOTO Y., NOMURA S., KAKIUCHI T. Potentiometric deter mination of $\mathrm{pH}$ values of dilute sulfuric acid solutions with glass combination electrode equipped with ionic liquid salt bridge. Journal of Electroanalytical Chemistry, 705 (1), 81, 2013.

20. SUDARSAN J.S., PRASANA K., NITHIYANANTHAM S., RENGANATHAN K. Comparative study of electricity production and treatment of different wastewater using microbial fuel cell (MFC). Environmental Earth Science, 73 (5), 2409, 2015.

21. VILLAVERDE S., LACALLE M., GARCIA-ENCINA P.A., FDZ-POLANCO F. Nitrification- denitrification of UASB effluents highly loaded with nitrogen in an activated sludge reactor operated with short cycled aeration. Water Science \& Technology, 44 (4), 279, 2001.

22. WANG A.J., DU D.Z., REN N.Q., GROENESTIJN J.W. An innovative process of simultaneous desulfurization and denitrification by Thiobacillus denitrificans. Journal of Environmental Science and Health, Part A, 40 (10), 1939, 2005.

23. WU C., LIU X.W., LI W.W., SHENG G.P., ZANG G.L., CHENG Y.Y., SHEN N., YANG Y.P., YU H.Q. A white-rot fungus is used as a bio-cathode to improve electricity production of a microbial fuel cell. Applied Energy, 98 (1), 594, 2012.

24. WU H., FU Y., GUO C., LI Y., JIANG N., YIN C. Electricity generation and removal performance of a microbial fuel cell using sulfonated poly (ether ether ketone) as proton exchange membrane to treat phenol/ acetone wastewater. Bioresource Technology, 260 (1), 130, 2018.

25. ZHANG F., CHEN M., ZHANG Y., ZHEN R.J. Microbial desalination cells with ion exchange resin packed to enhance desalination at low salt concentration. Journal of Membrane Science, 47 (1), 28, 2012. 